\author{
Marta ToMczok \\ Uniwersytet Śląski
}

\title{
Robinson w postantropocenie
}

Wierzę, że przyjda kiedyś czasy, gdy aeroplany nie będa sunęty po niebie jak stalowe, szare i groźne ptaki zniszczenia

(Słonimski 121)

\section{Założenia}

Celem artykułu nie jest dyskutowanie przydatności stosowania pojęcia „antropocen" i jego pochodnych (Braidotti 45-61), ale zastanowienie się nad postludzkim wymiarem robinsonady i realnymi korzyściami, jakie może przynieść lektura jej wybranych przykładów. Przez postantropocen będę rozumieć wyobrażenia dotyczące następstw końca ery człowieka formułowane w fikcjach alternatywnych takich jak Dwa końce świata Antoniego Słonimskiego. Analiza genologiczna utworu, zmierzająca do wykazania jego zależności od Robinsona Kruzoe Daniela Defoe, może stać się okazją do zbudowania refleksji pozagatunkowej, wykraczającej poza horyzont interpretacji utrwalonych dla słynnej osiemnastowiecznej powieści i macierzysty kontekst jej przedwojennego „naśladowania”. Pominięcie obu tych perspektyw, proponowane w artykule, wynika nie tyle $\mathrm{z}$ ich ograniczeń, stanowiących zagrożenie dla przyjętej interpretacji, ile z akceptacji ustaleń charakterystycznych dla tak zwanej historii preposteryjnej, „która zakłada, iż dzieło późniejsze [w tym wypadku zarówno proza Słonimskiego, jak i myśl postantropocentryczna, przedstawiona w postaci zbioru refleksji czy reguł M.T.] warunkuje (sposób, w jaki odczytujemy) dzieła wcześniejsze" (Maryl 321)1.

1 Kategoria preposteryjności Mieke Bal, omówiona w artykule Czytanie sztuki? (Bal), doczekała się kilku inspirujących eksplikacji, w tym między innymi komentarza Macieja Maryla (Maryl) i Agaty Stanowskiej (Stankowska). 
Realnym powodem podjęcia tego typu namysłu jest jednak brak opracowań powieści Słonimskiego w kontekście samej robinsonady. Jak dowodzą historycy literatury, nad Dwoma końcami świata zastanawiano się okazjonalnie, a kolejne wydania nie doprowadziły do gruntownego przebadania utworu (Będkowski 119; Haska, Stachowicz). Wątki, jakie podejmowano dotychczas, dotyczyły antyutopii, social science fiction, historii alternatywnych, totalitaryzmu i demokracji. W artykule O dawniejszych oraz współczesnych kontekstach „Dwóch końców świata” Antoniego Słonimskiego Leszek Będkowski wykazał, że jedyne powojenne wydanie tej powieści w 1991 roku przypadło na okres przemian politycznych, skierowanych w zupełnie inną stronę niż ta, która w 1937 roku interesowała Słonimskiego (Będkowski 122). Paradoksalnie, to właśnie dzisiaj znajdujemy się bliżej tamtego czasu, a realne zagrożenia społeczne, jak zbliżająca się katastrofa klimatyczna, wymieranie gatunków zwierząt, zwiększony ruch migracyjny, chwiejący porządkiem Europy, czy głęboki kryzys humanizmu i demokracji, stawiają prozę Słonimskiego w rzędzie najważniejszych scenariuszy przyszłościowych. Pozwala to z jednej strony na aktualizację samej lektury, a z drugiej na docenienie takich właściwości Dwu końców świata jak społeczne zaangażowanie, myślenie ich autora o przyszłości w kontekście teraźniejszości oraz afirmowanie cech „czysto ludzkich” jak skłonność do popełniania błędów i potrzeba ich naprawiania, uczenie się, poszukiwanie wyzwolenia od siebie w zajęciach praktycznych, a przede wszystkim dążenie do utrzymania wspólnoty międzyludzkiej.

Prawdopodobnie powieść Słonimskiego stanowi źródło koncepcji, wedle której możliwe jest połączenie dwu odległych zjawisk, prozy Defoe ze zburzeniem przez Niemców w 1944 roku Warszawy; niewykluczone też, że książka autora Murzyna warszawskiego przyczyniła się do powstania metafor „Robinson warszawski” i „Robinsonowie getta” (Leociak 827; Studniarek 65). Uzmysłowienie sobie katastroficznego wymiaru Dwu końców świata, a szczególnie prognostycznego, wręcz proroczego sensu powieści, powinno uczynić z niej tekst istotny także dla studiów nad Zagładą. W rozumieniu literatury Holokaustu, wprowadzonym przez Davida Roskiesa, możliwe jest zaliczanie do narracji o Zagładzie literatury wyprzedzającej, zapowiadającej bądź przeczuwającej nadchodzące ludobójstwo, choć - jak zaznacza badacz - wszelkie tego typu działania należy przeprowadzać z dużą ostrożnością (Roskies, Wolski 18-19). Robinsonada Słonimskiego z jednej strony wykazuje cechy przynależne modelowi adaptacyjnemu powieści Defoe (Ruszała), z drugiej wykracza poza sferę rozważań gatunkowych i lokuje się w strefie lęku oraz przeczuć końca. Daje więc badaczowi szerokie pole możliwości interpretacyjnych, pozwalające obserwować rozwój wątku robinsonowskiego, prawdopodobieństwo historyczne 
fikcji literackiej, jej potencjał ostrzegawczo-prognostyczny, a także współczesną aktualność, polegającą na zgodności niektórych konceptów Słonimskiego z myślą posthumanistyczną.

\section{„[...] jakżeż samotny jestem na tym świecie...”. Wokół Zagłady ${ }^{2}$}

W jednej z najbardziej przerażających, dokumentarnych robinsonad, Pianiście Władysława Szpilmana, przeczytamy:

Byłem sam. Nie na terenie domu czy nawet dzielnicy, lecz sam w całym mieście, które jeszcze niedawno liczyło półtora miliona ludzi i było jednym z bogatszych i piękniejszych miast Europy, dziś zaś legło w gruzach, pełne spalonych i zburzonych domów, pod którymi pogrzebane były zbierane od wieków zabytki kultury całego narodu i rozkładające się w cieple ostatnich dni tej jesieni ciała tysięcy pomordowanych ludzi (Szpilman 157).

Tematem tego fragmentu jest przeraźliwie bolesne doświadczenie samotności. Bohater przeżywa je intensywnie z powodu jego nieodwracalności - zmarli nie zmartwychwstaną, miasto nie odbuduje się z gruzów (przynajmniej nieprędko), a ukrywanie się pozostanie najbliższą perspektywą życiową Szpilmana przez kolejne długie miesiące 3 . Spośród trzech członów mitu Robinsona, na jakie $\mathrm{w}$ pracy Robinson $w$ literaturze polskiej. Teoria - historia - recepcja wskazała Jadwiga Ruszała, najwięcej wspólnego z samotnością ma motyw bezludnej wyspy (Ruszała 49). Wprawdzie badaczka utożsamia go także z arkadyjskim szczęściem i zaznaniem raju na ziemi, podkreśla jednak głównie stan psychiczny Robinsona (oddany jako rozpacz w adaptacjach powieści Władysława Ludwika Anczyca i Elwiry Korotyńskiej). Samotność w mniemaniu bohatera jest następstwem jego dawnych przewinień, a początkowy entuzjazm dla życia w izolacji ustępuje miejsca pragnieniu spotkania ludzi. Nieoczekiwanie dwa przenikliwe komentarze do powieści Defoe, napisane kilka lat po Zagładzie, prawie zupełnie pomijają ten wątek, rozwijają natomiast problematykę ekonomii, kapitalizmu, kupiectwa, księgowości i religii. Warto zastanowić się nad przyczynami tego przemilczenia.

2 Cytat pochodzi z życiorysu Daniela Defoe, umieszczonego w przedmowie do broszury A Replay to a Pamphlet, Entitled „The Lord Haversham's Vindication of His Speech... (Watt 103).

3 W podobny sposób o swojej samotności myśli inny Robinson warszawski, Jakub Szapiro, bohater Królestwa Szczepana Twardocha. 
Początek Szkoły klasyków Jana Kotta z 1949 roku, zatytułowany Narodziny powieści albo o Danielu Defoe, ujawnia silny związek Robinsona Kruzoe z czasem, w jakim powstała ta proza. W myśl tej interpretacji osiemnastowieczna powieść "zawiera w sobie ogromny kawał historii kapitalizmu i przemian mieszczaństwa” (Kott 9). I dalej:

Kupiec był rzeczywistym bohaterem Anglii wigów, był tym naturalnym człowiekiem, wolnym od pęt feudalnych, którego abstrakcyjny obraz stworzyli filozofowie Oświecenia. I dlatego literackim bohaterem epoki zostanie kupiec, który na bezludnej wyspie założy kapitalizm (Kott 21).

Formułując tę błyskotliwą tezę (kapitalizm na bezludnej wyspie), Kott wyraża nieoczekiwane u marksisty, przewrotne uznanie dla apologii kupiectwa, podziwiając w niej jednocześnie umiar i żarliwość, religijność i praktyczność (nie sposób tu nie powtórzyć złośliwej uwagi krytyka o prawdziwym powodzie napisania powieści, jakim była potrzeba zarobienia pieniędzy na posag dla najstarszej córki, „brzydkiej i garbatej” (Kott 25)). Drugi z komentarzy, późniejszy o kilka lat, pochodzi z pracy Watta o uderzająco podobnym tytule do wspomnianego rozdziału książki Kotta: Narodziny powieści. Bohatera prozy Defoe nazywa brytyjski historyk literatury homo economicus, a wszystkie jego zachowania i wybory, w tym zwłaszcza porzucenie rodziny, tłumaczy podporządkowaniem się zasadom wolnego rynku:

To, co Kruzoe nazywał swoim ,grzechem pierworodnym”, było w istocie dynamiczną tendencją samego kapitalizmu, który nigdy nie poprzestawał na zachowaniu status quo, lecz starał się ciągle go przekształcać. Porzucenie rodzinnego domu, dążenie do poprawy własnego losu były to kroki charakterystyczne dla modelu życia indywidualisty (Watt 73) ${ }^{4}$.

Odizolowanie jednostki od społeczeństwa, na które zwróci uwagę przede wszystkim Słonimski, Watt ocenia z perspektywy wymogów gatunku. Dydaktyzm powieści, za sprawą którego udało się przerobić samotność w samouctwo, nie ma nic wspólnego z realizmem psychologicznym. Oddanie go w narracji, tłumaczy Watt, byłoby kłopotliwe, dlatego prawdopodobnie pisarz świadomie zrezygnował z opisów samotności Robinsona, nie chcąc wikłać się w historie

4 Podstawę zestawienia obu prac stanowi przede wszystkim życiorys ich autorów: Kott, zasymilowany Żyd, ukrywał się po aryjskiej stronie Warszawy, Watt był więźniem japońskiego obozu pracy. Za zwrócenie mi na to uwagi dziękuję Pawłowi Wolskiemu. 
znane $\mathrm{z}$ The Voyages and Travels of J. Albert de Mandelslo. Ich bohaterowie-rozbitkowie popadali w szaleństwo z osamotnienia (Watt 10o). W zakończeniu szkicu o Defoe Watt krytycznie odnosi się do ekonomii osiemnastowiecznego indywidualizmu i neguje samotność z powodów towarzysko-społecznych:

Sceneria milczącego życia Kruzoego jest utopijna również i dlatego, że prawowite milczenie, przerywane jedynie od czasu do czasu okrzykiem papugi „Biedny Robinson Kruzoe”, nie narzucało człowiekowi - istocie charakteryzującej się egoizmem ontologicznym, obowiązku przybierania pozorów towarzyskiej konwersacji ani nie kazało mu w błazeński sposób udawać, że porozumiewa się z bliźnimi (Watt 105).

W ujęciu Watta to nie homo economicus, ale ludzka samotność stanowi katalizator rozwoju europejskiej powieści. Wprawdzie Robinson Kruzoe przemilcza temat relacji rodzinnych i erotycznych bohatera, zaś sprawę jego małżeństwa i potomstwa sprowadza do banału. Uwzględniająca wpływ wojny i Zagłady na społeczeństwo europejska krytyka nie mogła jednak pominąć tego tematu, przeciwnie, w koncepcie skrajnego indywidualizmu jako zagrożenia dla nowoczesnego społeczeństwa Watt zobaczył najistotniejszą misję powieści Defoe:

Opowieść Defoe’ego nie jest zapewne powieścią w zwykłym znaczeniu tego słowa, ponieważ zajmuje się stosunkami międzyludzkimi w znikomym stopniu. Jednak tradycja powieści powinna zaczynać się od dzieła, które odrzucając stosunki międzyludzkie zastanego systemu społecznego zwróciło uwagę na możliwość i potrzebę wybudowania systemu stosunków opartych na nowych, świadomych zasadach (Watt 106).

\section{Warszawska robinsonada}

Podsumowując dociekania na temat powieści Defoe, Kott zauważył, że dziwność jej recepcji wynika z sukcesywnego usuwania z Robinsona Kruzoe „wszystkiego, co w nim drapieżne i wielkie” (Kott 62) i wprowadzania się w to miejsce fabuły coraz bardziej wtórnej, okrojonej ze złożonych sensów i podobnej do „smutnych, sfałszowanych klasyków” (Kott 63). Miał to być sposób ludzkości na zniszczenie dzieła młodej burżuazji, pokazującego kształtowanie się klasy mieszczańskiej i kapitalizmu.

Dwa końce świata Słonimskiego nie należą do upraszczających oryginał adaptacji czy przeróbek. Nie przypominają też zjawiska nazywanego przez Ruszałę „zabawą w Robinsona” (Ruszała 133). Obecne w powieści toposy robin- 
sonowskie pełnią raczej funkcję komentarza kulturowego do takich problemów jak wynikające z wyludnienia osamotnienie człowieka czy groźba globalnej katastrofy skutkująca zagładą ludzkości. Słonimski rozważa także rolę Żydów w tym zniszczeniu, mierzy się z problemem antysemityzmu, próbuje zrozumieć i ocenić groźbę faszyzmu oraz poddać refleksji postaci Hitlera czy Mussoliniego. Ponieważ nie jest w stanie z wyprzedzeniem napisać prozy o Zagładzie, nie podejrzewa zresztą nawet, by jego intuicje miały się w całości spełnić, proponuje znany czytelnikowi schemat fabularny w celu oswojenia i ośmieszenia własnych obaw. Warte podkreślenia wydaje się zatem ironiczne „otoczenie” znanych robinsonotopów (Konarzewska 636) czy potraktowanie z przymrużeniem oka takich elementów mitu Robinsona jak bezludna wyspa i Piętaszek.

Analizując odniesienia Dwu końców świata do wzorca, należałoby powiedzieć, że powieść Słonimskiego jest raczej pararobinsonadą niż robinsonadą, ponieważ twórczo nawiązuje do trzech spośród sześciu robinsonotopów: pobytu głównego bohatera na bezludnej wyspie (1), krytycznego położenia i walki o przetrwanie (2) oraz wysiłku tworzenia dogodnych warunków egzystencji (3) (Konarzewska 636). Pozostałe trzy wątki, ucieczka z domu, rozbicie okrętu i obecność niesprzyjającej przyrody, są w niej wyciszone lub nieobecne.

Swobodne korzystanie przez Słonimskiego z wzorca fabularnego polega przede wszystkim na tym, że dwie najważniejsze dla autora części mitu robinsonowskiego, dotyczące Robinsona i Piętaszka, od razu zostają wprzęgnięte w machinę przekształceń i reinterpretacji. Czwarty rozdział powieści nosi tytuł w którym pan Szwalba zostaje Robinsonem warszawskim, a siódmy - w którym Robinson warszawski znajduje swojego Piętaszkas. Czego dotyczą te fragmenty utworu Słonimskiego? Pierwszy z nich zawiera szczegółowy opis położonej w Europie Zachodniej miejscowości Ruben, podobnej do obozu koncentracyjnego. Zarządza nią Hans Retlich, niemiecki antysemita i dziwak, członek partii hitlerowskiej (Słonimski 33) i komendant obozu koncentracyjnego w Osnabrück. Jego plan polega na zagładzie całej ludzkości za pomocą Niebieskich Promieni, które prowadzą do zwęglenia ludzkiego ciała i uczynienia z niego „sypkiej masy niebieskawego koloru” (Słonimski 6). Miejsce dawnych ludzi ma zająć nowa ludzkość, stworzona ze specjalnie „wyhodowanych” Lapończyków, społeczności, która - jak sądzi Retlich - nie ma w sobie domieszki krwi żydowskiej. Jeden

5 Znacznie bardziej rozpowszechnione jest wyrażenie „Robinson warszawski” (właściwie: Robinson Warszawski) w odniesieniu do tytułu filmu Jerzego Zarzyckiego z 1946 roku przedstawiającego losy popowstańczej Warszawy i ludzi z ruin. Na temat historii filmu, losów scenariusza przygotowanego przez Jerzego Andrzejewskiego i Czesława Miłosza oraz roli cenzury pisał Jacek Leociak (Leociak 827). 
$\mathrm{z}$ ataków tyrana zostaje wymierzony w Warszawę, opustoszając ją całkowicie z życia. Cudem ocalały pracownik księgarni, Henryk Szwalba, staje przed nieograniczonym wyborem - może zjeść, co chce, wynieść ze sklepu jakikolwiek alkohol, wyposażyć się w dowolną liczbę sprzętów i książek, zamieszkać gdzie bądź. Jego wybór pada na Hotel Europejski, a początek organizowania sobie nowego bytu przynosi wiele korzyści: „Szwalba z pustą walizką wyszedł na miasto, i przyznać trzeba, że znajdował niemałą satysfakcję w zagarnianiu najrozmaitszych przedmiotów" (Słonimski 43). Nie od razu Robinson warszawski odczuwa samotność. Początkowo porządkuje minioną przeszłość, układa w głowie najróżniejsze hierarchie, a trapi go jedynie fakt, że nie zdoła opublikować swoich zapisków poświęconych między innymi pochwale socjalizmu. Jedyna metafora robinsonowska, pojawiająca się w tym rozdziale, brzmi następująco: „nowy Robinson postanowił wyruszyć po skarby, jakie zostały na zatopionym w samotności okręcie wymarłej Warszawy” (Słonimski 43).

Z kolei rozdział poświęcony Piętaszkowi, którym okazuje się niejaki Chomiak, pozbawiony manier prostak, sprowadza się do opisu najróżniejszych perypetii związanych z jego utracjuszostwem - od alkoholizmu po marzenia pornograficzne. Dzięki niespodziewanemu towarzystwu Szwalba zdaje sobie sprawę z misji, jaką ma do wypełnienia: „Kto wie, dumał, czy jego obowiązkiem nie jest połączyć się z ludźmi, którzy pozostali przy życiu, i pracować w jakiś sposób dla ich przyszłości” (Słonimski 68). Od tej pory:

Szwalba wpadł w maniacki upór wynalezienia tych, którzy mogli pozostać przy życiu. Cały czas wolny od pisania pamiętnika i wspomnień, które miały być jak butelka rzucona w ocean, powierzone pustce wymarłej Warszawy, spędzał Szwalba na rozmyślaniach nad odnalezieniem ludzi (Słonimski 7o).

Zamiast zajęć praktycznych, zdobywania pożywienia czy umoralniających rozmów z Piętaszkiem nowy Robinson rozmyśla o możliwości dołączenia do ludzi, którzy mogli przetrwać promieniowanie. Cały jego wysiłek zostaje włożony w uwolnienie się od balastu samotności i przywrócenie światu stanu sprzed zagłady. W tym miejscu wkracza Słonimski z krytyką humanizmu i uświadamianiem odbiorcy, czym może być totalitaryzm. Niepohamowana tęsknota Szwalby za ludźmi nie wynika z jego przyzwyczajeń - dotąd wolał on czytać książki i uchodził za mizantropa. Bierze się natomiast z bezkrytycznego przyjęcia paradygmatu antropocentrycznego (nieważne, jacy są ludzie, ważne, by w ogóle byli) i rezygnacji z możliwości jego zweryfikowania, krytyki, unowocześnienia. Złączywszy się z brytyjskim profesorem Pankhurstem i jego 
asystentką, Szwalba podróżuje do Ruben, poznaje obóz koncentracyjny Retlicha, a następnie jest świadkiem jego upadku i początku nowej dyktatury Yara, Lapończyka. W wyniku tych doświadczeń Robinson warszawski ponownie traci zaufanie do ludzi i zaszywa się z książkami w jaskini.

Przedziwna, nietypowa robinsonada Słonimskiego, pozbawiona narracji dydaktycznej, opiera się prawie wyłącznie na próbach zrozumienia, co może oznaczać kres ludzkości. Nie wdając się w szczegóły, można na razie powiedzieć, że oznacza on koniec najtrwalszych wartości naszej kultury: sztuki, demokracji, nauki i religii.

\section{„Obecnie żyjemy w epoce lodowej serc": podsumowanie}

Wyrazem troski o kondycję humanizmu wydaje się tyrada Pankhursta nazwana przez Słonimskiego „pukaniem palca w ścianę”:

Jesteśmy we władzy dzikich. Lapończycy i rubenici są nam niechętni. Musimy jednak przetrwać działając, broniąc ustawicznie naszej postawy życiowej. Każdy krok naprzód, każde pozytywne osiągnięcie będzie zbliżało ich do nas. Kiedyś wreszcie zwycięski postęp podźwignie ludzkość do poziomu współdziałania. Skończą się walki rasowe czy klasowe. Siłą rozumu pokonane konflikty pozwolą na wychowanie nowej ludzkości wolnej od uczuć nienawiści (Słonimski 114).

Utopijna wizja przetrwania tradycji europejskiego humanizmu ma wiele wspólnego z Robinsonem Kruzoe. Wiara w ujarzmienie dzikości, cechująca głównego bohatera, wynika przede wszystkim z poczucia wyższości, charakterystycznego dla europocentryzmu. Pojawia się ono także u bohaterów $D w u$ końców świata, którzy nie są chętni, by poznawać obce cywilizacje czy wyzbyć się uprzedzeń wobec Żydów. Źródła odbudowy ludzkości upatrują w powtórnym, ale mocniejszym i głębszym „przeoraniu” kultury narzędziami humanizmu. Słonimski traktuje tego typu postawę jak kpinę $\mathrm{z}$ walki $\mathrm{z}$ totalitaryzmem i zarysowuje jeszcze wyraźniej perspektywę antyhumanistyczną, chcąc dowieść, że przywrócenie społecznego ładu po Hitlerze i Mussolinim nie będzie możliwe. Jego stanowisko wzmacnia kontekst posthumanistycznych prac Rosi Braidotti. Według filozofki posthumanizm oznacza koniec opozycji między humanizmem i antyhumanizmem oraz kres Człowieka/Mężczyzny/Kobiety. Przede wszystkim jednak stanowi odejście od samego humanizmu w kierunku alternatyw, pozwalających ominąć problem „kryzysu człowieka” (Braidotti 101). Jedną z nich tworzą tzw. „strukturalni inni” (Braidotti 101) - nowe formy podmiotowości 
umożliwiające przekroczenie tradycyjnego „ja” uwikłanego w kategorię rasy czy klasy. Jak przekonuje filozofka, nie warto cofać się do tradycji, ale trzeba dokonać skoku naprzód, w którym wybrzmi także kreatywność pojęciowa posthumanizmu.

Przykładem wyprzedzającego uwagi Braidotti myślenia może być powieść Słonimskiego, a szczególnie obraz nowych dzikusów, Lapończyków, którymi ma się wypełnić świat w przyszłości. Stają się oni kimś w rodzaju maszyn - nieczułymi, niemuzykalnymi, ale walecznymi i silnymi cyborgami. Ich zadaniem jest zaludnić ziemię swoją „naturalną i przyrodzoną, wspaniałą zwierzęcością” (Słonimski 37). Przeciwieństwem Lapończyków są natomiast Żydzi. Ich „zła krew” płynie prawie we wszystkich ludzkich żyłach, od polskich po afrykańskie. Oprócz teorii spisku światowego bohaterowie powieści Słonimskiego przypisują Żydom także inne absurdalne czyny jak zwabienie ludzkości na ląd (według jednego z profesorów z Wrocławia ludzie byli najszczęśliwsi, przebywając pod wodą) i zachowanie skrzeli („Łatwowierne narody aryjskie uległy podszeptom międzynarodowego żydostwa i zaczęły oddychać płucami” (Słonimski 15)) Żydem jest także sam Szwalba, czego od nikogo bezpośrednio się nie dowiemy. Jego tożsamość zostaje wyjawiona przy okazji, podczas powitania z Chomiakiem, i staje się przez chwilę przeszkodą w przyjaźni Piętaszka z Robinsonem.

Najbardziej zastanawiająca scena Dwu końców świata wiąże się z ponownym wyborem samotności przez głównego bohatera. Oto przejechawszy tysiące kilometrów w poszukiwaniu ludzi, i to także tych stanowiących bezpośredni instrument władzy tyrana Retlicha, Szwalba rezygnuje ze swojej misji i postanawia zaszyć się z powrotem z książkami, by wieść żywot odludka (jaskiniowca). Akt ostatecznej kapitulacji łączy się także z pustką Warszawy: jej ruiny są dalej czarne, a krajobraz - księżycowy. Robinson warszawski to zatem wieczny jaskiniowiec, skazany na ukrywanie się w gruzach i ruinach, samotnik pozbawiony złudzeń i zaufania do świata. Nieoczekiwany los tego rozbitka skupia w sobie podobnie jak miało to miejsce w XVIII wieku - najistotniejsze problemy epoki: próbę zmierzenia się z katastrofą i zawalczenia o ludzkość, zakończoną totalną klęską humanizmu. Polega ona między innymi na zaniechaniu komunikacji między cyborgami z Laponii a Europejczykami, co przyczynia się do spotwornienia systemu politycznego przywódcy rubenitów i wykształcenia się struktur władzy autorytarnej. Paradoksalnie, to wersja Słonimskiego, przedstawiająca życie człowieka na pustkowiu, wydaje się bardziej prawdopodobna niż wersja

6 Przez „przypisywanie” nie należy rozumieć tożsamości poglądów narratora i autora, ale raczej efekt identyczności ich stanowisk wynikający z przyjętej przez Słonimskiego strategii szydzenia z prymitywizmu myślowego antysemitów. 
Defoe, mimo iż to polski pisarz nazywa swojego bohatera „podobnym do Robinsona z dziecięcych ilustracyj” (Słonimski 44), ujawnia więc infantylność własnych inspiracji.

Figura Robinsona w postantropocenie diagnozuje kryzys europejskiego humanizmu w sposób modelowy. Z jednej strony przywołuje tradycję, opartą na wierze w naukę i postęp, z drugiej ostrzega przed Zagładą. Należy w przywołanej figurze widzieć także krytykę możliwości ludzkiego rozumu w sferze zarówno spekulacji, jak i formułowania wniosków na podstawie popełnionych błędów; sygnalizuje ona przegraną, zapowiada klęskę wiary w demokrację, dowodzi, że błąd poznawczy Europy wynika ze zlekceważenia jej wewnętrznych konfliktów (antysemityzm) i niedocenienia terytoriów położonych daleko od centrum (Północ). Bezludnej wyspy nie udaje się przywrócić do życia, a świata odbudować - postludzki wymiar robinsonady polega więc na zrozumieniu, że kres człowieka nie musi oznaczać raju, w którym rozkwitnie życie przechowane w Arce. W rozmowie Pankhursta ze Szwalbą mówi się o oczekiwaniu na pokój - jego symbolem mają być kolorowe samoloty latające beztrosko po niebie jak ptaki. Uwolniona z więzów techniki i służby człowiekowi maszyna może prowadzić beztroski, próżniaczy żywot. Słonimski zaznacza, że nie powinno się jednak traktować utraty hegemonii przez Europę jako jej końca, ale zobaczyć w niej szansę na zaistnienie innych form życia, wyłączonych z rządów zarówno demokratycznych, jak i totalitarnych.

\section{| Bibliografia}

Bal, Mieke. „Czytanie sztuki?”. Przeł. Maciej Maryl. Teksty Drugie 1-2 (2012). S. 39-58.

Będkowski, Leszek. „O dawniejszych oraz współczesnych kontekstach «Dwóch końców świata» Antoniego Słonimskiego”. Literatura popularna. T. 1. Red. E. Bartos, M. Tomczok. Katowice: Wydawnictwo Uniwersytetu Śląskiego, 2013. S. 119-135.

Braidotti, Rosi. Po człowieku. Przeł. Joanna Bednarek, Agnieszka Kowalczyk. Warszawa: PWN, 2014.

Haska, Agnieszka, Stachowicz, Jerzy. Śniąc o potędze. Warszawa: Narodowe Centrum Kultury, 2012.

Konarzewska, Marta. „Robinsonada”. Słownik rodzajów i gatunków literackich. Red. Grzegorz Gazda, Słowinia Tynecka-Makowska. Kraków: UnIVERsitas, 2006. S. 635-639. 
Kott, Jan. Szkoła klasyków. Warszawa: Czytelnik, 1955.

Leociak, Jacek. „Epilog: Miejsce-Po-Getcie”. Engelking Barbara, Leociak Jacek. Getto warszawskie. Przewodnik po nieistniejącym mieście. Warszawa: Stowarzyszenie Centrum Badań nad Zagładą Żydów, 2013. S. 820-837.

Maryl, Maciej. „Sztuka czytania? Mieke Bal w teorii i w praktyce”. Teksty Drugie, 4 (2013). S. 312-326.

Roskies David G., Wolski Paweł. „Nie spieszy mi się domykać kanon” [rozmowa]. Narracje o Zagładzie 1 (2015). S. 15-30.

Ruszała, Jadwiga. Robinson w literaturze polskiej. Teoria - historia - recepcja.

Słupsk: Wyższa Szkoła Pedagogiczna. Wydawnictwa Uczelniane, 1998.

Słonimski, Antoni. Dwa końce świata. Warszawa: Książka i Wiedza, 1991.

Stankowska, Agata. Ikona i trauma. Pytania o „obraz prawdziwy” w liryce i sztuce polskiej drugiej połowy xx wieku. Kraków: Universitas, 2019.

Studniarek, Michał. „Dzieje warszawskich Robinsonów jako problem badawczy”. Dzieje najnowsze 2 (2015). S. 63-78.

Szpilman, Władysław. Pianista. Warszawskie wspomnienia 1939-1945. Wstęp i oprac. A. Szpilman. Fragmenty pamiętnika W. Hosenfeld. Posłowie W. Biermann. Kraków: Wydawnictwo Znak, 2001.

Watt, Ian. Narodziny powieści. Studia o Defoe’em, Richardsonie i Fieldingu. Przeł. Agnieszka Kreczmar. Warszawa: Państwowy Instytut Wydawniczy, 1973.

\section{| Abstrakt}

\section{Marta TOMCZOK}

\section{Robinson w postantropocenie}

W artykule podjęto próbę wyjaśnienia związków wyrażenia „Robinson warszawski” z powieścią Robinson Kruzoe Daniela Defoe i współczesnym nawiązaniem do niej w futuresce Dwa końce świata Antoniego Słonimskiego. W części analitycznej wykazano zależność prozy Słonimskiego od wzorca fabularnego oraz eseistyki Jana Kotta i Iana Watta poświęconej przekroczeniu perspektywy indywidualistycznej w powieści europejskiej. W zakończeniu postawiono pytanie o preposteryjną lekturę Dwu końców świata w kontekście koncepcji posthumanizmu Rosi Braidotti.

Słowa kluczowe: Zagłada, Robinson warszawski, postantropocen 


\section{| Abstract}

Marta ToMczoK

\section{Robinson in Post-Anthropocene}

This article attempts to explain the relationship between the expression „Robinson of Warsaw” and the novel Robinson Crusoe by Daniel Defoe and a contemporary reference to it in the futureska Two Ends of the World by Antoni Słonimski. The analytical part demonstrates the dependence of Słonimski's prose on the role model and essay writing by Jan Kott and Ian Watt devoted to exceeding the individualistic perspective in the European novel. Towards the end, a question is asked about the preposterous reading of Two Ends of the World in the context of Rossi Braidotti's concept of posthumanism.

Keywords: Holocaust, Robinson of Warsaw, post-anthropocene

\section{| Nota o autorze}

Marta Tomczok - badaczka Zagłady i jej najnowszych reprezentacji kulturowych, pracuje na Wydziale Humanistycznym Uniwersytetu Śląskiego. Autorka m.in. książek Czyja dzisiaj jest Zagłada? Retoryka - ideologia - popkultura (Warszawa 2017) oraz Czy Polacy i Żydzi nienawidza się nawzajem? Literatura jako mediacja (Łódź 2019). Redaktor naczelna „Narracji o Zagładzie”. Publikowała m.in. w „Tekstach Drugich”, „Pamiętniku Literackim”, „Ruchu Literackim”, „Zagładzie Żydów. Studia i Materiały”, „Pracach Filologicznych. Seria Literaturoznawstwo”, „Poznańskich Studiach Polonistycznych”, „Poznańskich Studiach Slawistycznych”. Współpracuje z „Nowymi Książkami”.

E-mail: marta.tomczok@us.edu.pl 